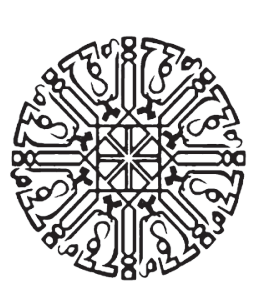

\title{
Konsepsi Marital Rape dalam Fikih Munakahat
}

\author{
M. Irfan Syaifuddin \\ IAIN SURAKARTA \\ nafryza84@iain-surakarta.ac.id
}

\begin{abstract}
Abstrak
Marital rape menjadi kajian penting dalam isu-isu gender dalam beberapa dekade terakhir di Indonesia. Para penggiat kesetaraan gender -khususnya feminist - menggambil peran dalam menyuarakan marital rape sebagai bagian kekerasan dalam rumah tangga, yang bagi pelakunya bisa dikenai pidana. Terbitnya UU No. 23 Tahun 2004 tentang Penghapusan Kekerasan Dalam Rumah Tangga (PKDRT) menjadi jawaban terhadap kegelisaan para penggiat HAM khususnya untuk perempuan akan keberpihakan negara dalam melindungi setiap warga yang mendapatkan tindakan kekerasan sekalipun dalam ruang private, yaitu rumah tangga. Jika sebelumnya, kekerasan dalam rumah tangga tidak diatur khusus dalam KUHP dan hanya menjadi delik aduan umum, dalam UU PKDRT diatur dengan jelas dan rigid, marital rape dikategorikan ke dalam kekerasan seksual dan pelakunya dikenai hukuman pidana 12 tahun penjara atau denda sebesar 36 juta rupiah. Namun menjadi ironi jika kita melihat ke dalam litaratur fikih munakahat belum banyak dikemukakan pendapat ahli tentang bagaimana konsep dan hukum marital rape. Maka menumbuhkan kesadaran para ahli fikih akan petingnya konsep marital rape mutlak diperlukan, sehingga bukan hanya berdasar kepada ketentuan dalam hukum positif saja, tapi ketentuan dalam hukum Islam yang tegas terhadap marital rape.
\end{abstract}

Kata kunci: Marital rape, KDRT, Fikih Munakahat.

\section{Pendahuluan}

Membangun keluarga sebagai wadah relasi suami istri merupakan harapan ideal bagi setiap Muslim dewasa. Keluarga selain menjadi satu-satunya cara yang dibolehkan dalam Islam bagi laki-laki dewasa dan perempuan dewasa untuk berhubungan seksual, juga sebagai jalan untuk memenuhi kebutuhan dasar (al-masalah adh-dhoruriyyah) dalam maqasid syariah yaitu memelihara keturunan (fungsi reproduksi). Maka untuk melaksanakan fungsifungsi keluarga tersebut, dibutuhkan keserasian dan kerja sama antara suami istri sehingga 
mampu menjalan tugas dan tanggung jawab tanpa mengabaikan hak masing-masing. Namun, tidak selamanya keserasian dan kerja sama antara suami istri bisa terwujud dengan baik, terkadang salah satu atau keduanya lalai atau mengabaikan tugas dan tanggung jawab dan melanggar hak sehinga menimbulkan konflik dalam rumah tangga. Jika konflik dalam rumah tangga dibiarkan maka bisa menimbulkan kekerasan yang dilakukan satu pihak ke pihak lain (suami ke istri atau sebaliknya) dalam rumah tangga.

Kekerasan dalam rumah tangga (KDRT) merupakan fenomena sosial yang dalam beberapa dekade terakhir banyak dibicarakan oleh para penggiat HAM dan feminist di forumforum resmi lokal, regional, maupun nasional. Forum-forum diskusi publik tentang KDRT diadakan sebagi respon atas padangan masyarakat Indonesia selama ini yang cenderung apatis terhadap isu-isu KDRT dan menganggap bahwa masalah KDRT merupakan hal tabu jika diperbincangkan dalam ruang publik. Muncul stigma dalam masyarakat bagi seseorang -khususnya perempuan- berbicara masalah rumah tangganya kepada orang lain atau dalam forum yang lebih luas, terlebih jika yang dibicarakan adalah masalah KDRT. Masyarakat memandang bahwa masalah KDRT harus dirahasiakan dan dijaga agar tidak ditahui oleh orang lain (silence in honor).

Pepatah orang Jawa yang sering diberikan kepada para calon pengantin saat upacara perkawinan adalah "mikul dhuwur mendem jero" yang berarti setiap anggota keluarga harus menjunjung tinggi kehormatan keluarga dan memendam dalam atau merahasiakan dengan rapat semua keburukan keluarga. Perempuan dalam tradisi masyarakat Indonesi diposisikan pada posisi "luhur" dalam lingkungan rumah tangga, yang secara langsung memberikan kewajiban kepada perempuan untuk melaksanakan tugas "suci" menjaga keutuhan rumah tangga sekalipun dengan mengabaikan permasahan dirinya seperti menjadi korban kekerasan suaminya. Perasaan perempuan tidak lebih penting dibanding keutuhan dan keharmonisan rumah tangga(Munir, 2005, 10)such submission being portrayed as divine order. Some of the men interviewed in this study defended their dominant position by exaggerating the interpretation of religious texts that grant special privileges to men. Because of its serious repercussions on women, and because it runs counter to the basic principles of Islam on justice and equality and the overall objective of sharia, i.e. maslahat (benefit, well being. Setiap orang seharusnya membicarakan hal-hal baik tentang keluarga dan tidak membicarakan masalah atau kekurangan dalam keluarga.

Sejarah panjang perjuangan para penggiat HAM dan aktivis perempuan Indonesia dalam mendapatkan keadilan terhadap masalah KDRT dari pemerintah. Sejak negara Indonesia berdiri di tahun 1945, pemerintah belum menetapkan satu aturan khusus yang mengatur tentang KDRT. Ketentuan dalam KUHP tentang tindak pidana penganiayaan tidak mengatur hukuman bagi pelaku KDRT jika tidak terdapat bukti penganiayaan (luka berat) atau sampai menjadi korban (terbunuh), pelaku tidak bisa diberi hukuman jika masih dalam 
percobaan penganiayaan. Sampai pada tahun 2004, pemerintah Indonesia menetapkan UU No 23 Tahun 2004 tentang Penghapusan Kekerasan Dalam Rumah Tangga (PKDRT), menjadi puncak perjuangan dalam menegakkan keadilan dalam masalah KDRT di negara Indonesia.

Kekerasan yang dipersepsikan oleh masyarakat selama ini adalah kekerasan fisik, siksaan atau penganiayaan yang menyebabkan korban menderita dengan luka baik ringan atau berat. Masyarakat menganggap bahwa seseorang (mayoritas istri dalam rumah tangga) menderita jika menjadi tidak berdaya karena luka yang didapatkan, kemudian baru memberikan advokasi dan menyelesaikan masalah dengan damai. Persepsi masyarakat tentang tindak kekerasan adalah jika seseorang menjadi korban tindakan orang lain yang dibuktikan secara langsung akibat dari tindakan tersebut, seperti luka atau pingsan. Persepsi ini terlegitimasi oleh ketentuan dalam KUHP pasal 86 yang berbunyi: "Membuat orang pingsan atau tidak berdaya disamakan dengan menggunakan kekerasan"(Soeroso, 2012, 58).

KDRT sebetulnya bukan saja dibatasi kepada kekerasan fisik, namun juga masuk dalam lingkup KDRT adalah kekerasan psikis, verbal, dan sexual. Kekerasan atau pemaksaan sexual (marital rape) yang dilakukan suami kepada istri sering diabaikan, karena terdapat anggapan bahwa masalah sexual antara suami-istri adalah masalah intim dan private yang tanggung jawabnya ada pada suami dan istri. Sehingga banyak korban (istri) yang memilih diam dan tidak mempermasalah kekerasan atau pemaksaan seksual oleh suami. Terlebih jika menggunakan doktrin agama untuk melegitimasi tindakan suami meminta istri untuk melayani kebutuhan seksualnya.

Indonesia sebagai negara Muslim terbesar di dunia, telah mengundangkan sejumlah peraturan perundang-undangan terkait hukum keluarga (al-ahwal asy-syahsiyyah) yang berpedoman kepada tata aturan dalam fiqih Islam khususnya fiqh munakahat. Fiqih munakahat mengatur semua aspek kehidupan keluarga tak terkecuali tentang hak dan kewajiban suami-istri dalam berhubungan seksual. Setiap pasangan suami-istri harus menjalankan hubungan seksual yang baik, yang seimbang dan adil. Namun masih terdapat stereotip di masyarakat bahwa istri yang menolak ajakan hubungan seksual suaminya akan dilaknat sampai pagi, bahkan tindakan kekerasan -misalnya memukul- kepada istri sebagai salah satu cara suami mendidik istri yang nusyuz masih menjadi doktrin yang dipegang kuat oleh masyarakat, karena memang disebut dalam al-Qur'an. Walaupun penafsiran ayat nusyuz tidak seharusnya secara tekstual namun dilakukan secara holistik karena dalam ayat yang lain Allah memerintahkan suami untuk mempergauli istrinya dengan baik atau ma'ruf.

Berdasar kepada latar belakang di atas, maka pemahaman komprehensif terhadap masalah marital rape dalam kajian figh munakahat mutlak diperlukan sesuai dengan semangat emansipasi perempuan dan kesetaraan gender menuju kehidupan berkeadilan yang menjadi hak asasi setiap manusia. Artikel ini memberikan gambaran tentang 
bagaimana konsepsi marital rape dalam figh munakahat sebagai usaha untuk memberikan pemahaman sekaligus kesadaran kepada masyarakat Muslim tentang menjaga kebaikan hubungan suami-istri dalam rumah tangga.

\section{MaritalRape sebagai Kekerasan dalam Rumah Tangga}

KDRT merupakan bagian dari tindak kekerasan yang oleh ketentuan hukum positif (perundang-undangan di Indonesia ataupun hukum internasional) bagi pelaku dikenai ketentuan pidana. Masyarakat internasional telah mengkategorikan kekerasan dalam rumah tangga (KDRT) dalam tindak pidana kekerasan yang bagi pelakunya bisa dihukum secara pidana sekalipun pelaku adalah keluarga korban, sebagai upaya dalam pemberantasan tindak kekerasan pada perempuan khususnya dalam rumah tangga. KDRT diartikan sebagai tindak kekerasan yang terjadi dalam ruang lingkup pribadi yaitu rumah tangga, antara pasangan atau anggota keluarga. KDRT terjadi ketika seseorang memaksakan kehendaknya kepada orang lain dalam rangka untuk menunjukkan penguasaan dalam suatu keluarga, umumnya dalam bentuk kekerasan yang terkait dengan identitas gender, seperti pelecehan seksual, perkosaan, dan intimidasi dengan fisik atau verbal. (Martha, 2011, 2)

Terdapat beberapa terminologi yang menjadi konsensus internasional tentang kekerasan terhadap orang lain, yaitu violence, battery, dan assult. Violence didefinisikan sebagai suatu tindakan pemaksaan yang disertai dengan ancaman, kekerasan, atau tindakan kasar kepada orang lain. Battery dikategorikan dalam suatu tindakan melanggar hukum yang dilakukan seseorang dengan sadar (mempunyai motivasi melakukan kekerasan atau pemaksaan) kepada orang lain yang berakibat melukai atau menghilangkan nyawa. Sedang assult dimaknai sebagai suatu tindakan yang memaksa korban untuk timbul rasa takut atau khawatir dari ancaman yang akan melukai dirinya, sekalipun tidak mesti dilakukan dengan memegang, memukul, atau tindakan berbahaya lainnya yang ditujukan kepada korban. (Soeroso, 2012, hlm. 59)

Istilah KDRT dalam literatur internasional digunakan dalam beberapa versi, seperti domestic violence, family violence, dan wife abuse. Kata domestic atau family menunjukkan bahwa kekerasan dilakukan oleh anggota keluarga kepada anggota keluarga yang lain, walaupun banyak kasus yang terjadi adalah kekerasan yang dilakukan seseorang kepada pasangannya (spause atau wife abuse). Karena pasangan tidak selalu istri, bisa calon istri atau pasangan hidup bersama dalam satu rumah. Kekerasan terhadap pasangan bisa dilakukan oleh perempuan kepada laki-laki (istri kepada suami) atau laki-laki kepada perempuan. Namun korban KDRT yang umumnya adalah perempuan (istri, anak, pasangan, orang tua, ataupun pembantu) yang disebabkan perbedaan kekuatan fisik dan sisi emosional yang cenderung muncul pada laki-laki, sementara perempuan cenderung lebih lemah secara fisik dan menunjukkan sifat lembut. (Martha, 2011, 3-4)

al-ạ̣kām Vol. 3, Nomor 2, 2018 
Secara umum KDRT ataupun kekerasan pada perempuan dibagi ke dalam empat kategori kekerasan, yaitu: kekerasan fisik, kekerasan emosi, kekerasan seksual, dan kekerasan verbal. Keempat kategori kekerasan berdasarkan tindakan pelak yang ditujukan kepada korban. Kekerasan dalam pandangan sebagian dari masyarakat hanyalah yang bersifat fisik karena kekerasan fisik dapat dibuktikan dengan adanya luka yang didapati oleh korban, sementara kekerasan dalam bentuk lain seperti makian, ejekan, kurungan, perampasan hak dan sumber daya personal cenderung diabaikan.(Martha, 2011, 5)

Menurut penjelasan UU No. 23 Tahun 2004 tentang Penghapusan Kekerasan dalam Rumah Tangga (PKDRT) pasal 1 ayat 1 bahwa kekerasan bukan saja dibatasi kepada kekerasan fisik, namun segala bentuk kekerasan yang berakibat pada penderitaan fisik, seksual, psikologi, dan penelantaran. Penjelasan tentang KDRT dinyatakan sebagai berikut:

"Kekerasan dalam Rumah Tangga adalah setiap bentuk perbuatan terhadap seseorang terutama perempuan, yang berakibat timbulnya kesengsaraan atau penderitaan secara fisik, seksual, psikologi, dan/atau penelantaran rumah tangga termasuk untuk melakukan perbuatan, pemaksaan, atau perampasan kemerdekaan secara melawan hukum dalam lingkup rumah tangga."

Keempat kategori KDRT atau kekerasan pada perempuan yang disebutkan dalam UU PKDRT dapat dijelaskan sebagai berikut:

1. Kekerasan fisik

Kekerasan fisik dapat berupa penyerangan fisik dengan cara mendorong, mencubit, menendang, memukul dengan atau tanpa alat, mencekik, menyiram dengan air panas atau air keras, melukai dengan senjata tajam atau senjata api, membakar, dan semua tindakan yang menghasilkan luka memar, luka gores bahkan kematian. Kekerasan fisik dalam beberapa kasus juga dilakukan bersamaan dengan kekerasan seksual, seperti peyerangan kepada organ-organ seksual (payudara dan kemaluan), juga persetubuhan paksa (perkosaan).

Kekerasan fisik umumnya didahului dengan ancaman, bisa secara langsung dengan ucapan atau gerak tubuh, dan secara tidak langsung seperti ancaman lewat pesan, telpon, atau orang lain.(Martha, 2011, 5-6)

2. Kekerasan seksual

Kekerasan seksual adalah pemaksaan atau ancaman kepada perempuan yang bersifat seksual untuk melakukan hubungan seksual dengan pelaku atau melakukan hubungan seksual dengan orang lain karena motif uang (human trafficking), Pasal 8 huruf b UU PKDRT menyebutkan: "pemaksaan hubungan seksual terhadap salah seorang dalam lingkup rumah tangganya dengan orang lain untuk tujuan komersil dan/atau tujuan tertentu." Ketentuan pidana terhadap kekerasan seksual seperti tersebut dalam pasal 8 huruf $b$ di atas ditentukan dalam pasal 47 yang berbunyi: 
"Setiap orang yang memaksa orang yang menetap dalam rumah tangganya melakukan hubungan seksualsebagaimana dimaksud dalam Pasal 8 huruf $b$ dipidana dengan pidana penjara paling singkat4 (empat) tahundan pidana penjara paling lama 15 (lima belas) tahun atau denda paling sedikit Rp 12.000.000,00 (dua belasjuta rupiah) atau denda paling banyak $\mathrm{Rp} 300.000 .000,00$ (tiga ratus juta rupiah)."

Kekerasan seksual bisa terjadi dalam hubungan suami istri bila dilakukan tanpa persetujuan, pencabulan, kontrol seksual akan hak menghasilkan keturunan, dan berbagai bentuk kecurangan yang dilakukan sehingga menyebabkan penderitaan secara emosi, sexual, ataupun fisik, yang kemudian disebut marital rape. (Martha, 2011, 5-6)

Kasus marital rape umumnya suami melakukan kekerasan atau intimidasi terhadap istrinya untuk melakukan hubungan seksual tanpa keinginan istri, yang kemudian menghadapi masalah ke hamilan yang tidak diinginkan (karena melakukan hubungan seksual tanpa menggunakan alat kontrasepsi), terkena penyakit seksual, juga trauma atau luka akibat pemaksaan kepada istri yang siap melakukan hubungan seksual.

3. Kekerasan Psikologis

Kekerasan psikologis merupakan perbuatan yang mengakibatkanketakutan, hilangnya rasa percaya diri, hilangnya kemampuan untuk bertindak, rasa tidak berdaya, dan/ataupenderitaan psikis berat pada seseorang. Kekerasan psikologis biasanya adalah dampak dari kekerasan atau ancaman fisik maupun seksual. Dampak kekerasan yang dialami mungkin berbeda antara satu perempuan dengan yang lain tergantung kepada kondisi psikologis seseorang. Beberapa kasus yang terjadi menyimpulkan bahwa kekerasan psikologis dampaknya lebih menyakitkan dibanding dengan kekerasan fisik.

Terdapat dua alasan yang menguatkan bahwa kekerasan psikologi jauh lebih berdampak jika dibandingkan dengan kekerasan fisik. Pertama, kekerasan psikologis dapat merusak kehormatan seseorang, melukai harga diri seseorang, merusak keseimbangan jiwa, sekalipun kekerasan psikologis tidak akan merusak organ tubuh bagian dalam dan mengakibatkan kematian. Kedua, kekerasan fisik lebih mudah diukur, seperti luka memar, luka gores, patah tulang, mulut berdarah, dan yang lain yang bisa diuji atau divisum oleh medis, sementara kekerasan psikologis tidak mudah diukur dan divisum.

4. Penelantaran

Penelantaran adalah suatu tindakan seseorang membiarkan orang lain yang berada dalam lingkup ruang tangga sehingga membuat tergantung dan tidak berdaya secara ekonomi.(Martha, 2003, 37)Penelantaran merupakan bagian dari kekerasan ekonomi, karena penelantaran membuat seseorang melakukan kontrol penuh terhadap peri kehidupan ekonomi anggota keluarganya. Contohnya seorang suami memaksa atau melarang istri bekerja untuk memenuhi kebutuhan keluarga, tidak memberi uang 
belanja, atau mengambil uang istri dengan semena-mena. Ketentuan dalam UU PKDRT diatur dalam pasal 9 ayat (1) yang berbunyi:

"Setiap orang dilarang menelantarkan orang dalam lingkup rumah tangganya, padahal menurut hukumyang berlaku baginya atau karena persetujuan atau perjanjian ia wajib memberikan kehidupan,perawatan, atau pemeliharaan kepada orang tersebut."

Juga dalam ayat (2) disebutkan:

"Penelantaran sebagaimana dimaksud pada ayat (1) juga berlaku bagi setiap orang yang mengakibatkanketergantungan ekonomi dengan cara membatasi dan/atau melarang untuk bekerja yang layak di dalam atau di luar rumah sehingga korban berada di bawah kendali orang tersebut."

Sementara kekerasan verbal diartikan sebagai bentuk kekerasan yang dilakukan seseorang dengan mengucapkan kata-kata kasar, menghina, mencela, dan merendahkan orang lain. Kekerasan verbal pada umumnya diikuti dengan sikap kasar atau marah dan merupakan komunikasi destruktif yang menyerang kepribadian seseorang (self-concept) sehingga menjadikan tidak berdaya dan menumbuhkan sikap atau emosi yang negatif dalam diri seseorang. Sekalipun kebanyakan kekerasan verbal muncul secara tiba-tiba akibat stress atau kondisi kejiwaan yang labil, namun dalam beberapa kasus kekerasan verbal dilakukan secara sadar dengan tujuan untuk mengotrol atau memperdaya orang lain untuk mewujudkan keinginan pelaku.(Bosch, 2007, 1)

Marital rape pada kenyataannya tidak dalam satu bentuk atau model tertentu, namun terdapat tiga bentuk kekerasan sexual yang dilakukan suami kepada istri,(Susilo, 2013, 320) yaitu:

1. Battering rape: suami melakukan kekerasan sexual dan kekerasan fisik sekaligus saat memaksa istri untuk melakukan hubungan seksual. Beberapa istri bahkan terluka secara fisik akibat pemaksaan yang dilakukan suami pada saat istri tidak siap atau tidak berkeinginan untuk melakukan hubungan seksual. Marital rape pada umumnya terjadi dalam bentuk ini.

2. Force-only rape: suami memaksa atau mengancam istri sebelum berhubungan seksual. Pemaksaan atau ancaman ini dilakukan agar istri mau melayani hasrat suami. Jika suami telah melampiaskan hasrat seksual kepada istrinya, maka suami tidak melakukan kekerasan fisik. Namun bila suami tidak terpenuhi hasratnya, mungkin bisa melakukan kekerasan fisik kepada istri.

3. Obsessive rape: istri atau pasangan mendapat kekerasan seksual dalam bentuk perilaku sadistic dalam melakukan hubungan seksual. Perilaku sadistic dalam hubungan seksual, yaitu suami melakukan kekerasan fisik seperti memukul, menarik rambut, mencekik atau bahkan menggunakan alat tajam yng melukai istri untuk mendapatkan kepuasan seksual dengan penderitaan istri atas kekerasan tersebut. 


\section{Upaya penghapusan Marital Rape}

Sejarah penghapusan KDRT telah tercatat sejak enam abad sebelum Masehi pada zaman Kerajaan Assyirian. Dikatakan bahwa setiap suami yang menganiaya istri akan dijatuhi pidana berupa potong jari, dan istri yang memukul suami akan dikenai denda dan dipukul dengan rotan sebanyak duapuluh kali.(Martha, 2011, 13)

Selanjutnya dalam perundang-undangan modern, KDRT khususnya kekerasan seksual kepada pasangan (marital rape) mulai diundangkan sejak awal abad ke duapuluh. Negaranegara yang membuat undang-undang khusus tentang marital rape adalah Uni Soviet di tahun 1922, Polandia tahun 1932, Cheko tahun 1950, Denmark tahun 1960, Swedia tahun 1965, Norwegia tahun 1971, dan beberapa negara blok Timur (komunis). Sedang negaranegara di bagian Amerika Utara dan Eropa Barat sampai tahun 1980an belum menganggap marital rape sebagai suatu tindak kejahatan yang perlu diundangkan aturan khusus, bahkan sampai tahun 1997, hanya 17 negara yang ada di kawasan Amerika Utara dan Eropa Barat yang membuat ketentuan pidana khusus untuk kejahatan marital rape.(Susilo, 2013, 322)

Penghapusan tindak kejahatan marital rape dalam ketentuan perundangundangan di Indonesia mempunyai sejarah panjang dan pengorbanan besar dari para pejuang kesetaraan dan keadilan bagi para perempuan di Indonesia. Terdapat sejumlah peraturan perundang-undangan di Indonesia,(Soeroso, 2012, 89-90) yang dijadikan dasar diundangkannya UU Nomor 23 Tahun 2004 tentang PKDRT (yang di dalam ketentuan pasal 8 point a mengatur tentang ketentuan marital rape), yaitu:

1. Undang-undang Nomor 1 Tahun 1946 tentang Kitab Undang-undang Hukum Pidana (KUHP) serta perubahannya;

2. Undang-undang Nomor 7 Tahun 1981 tentang Kitab Undang-undang Hukum Acara Pidana (KUHAP);

3. Undang-undang Nomor 1 Tahun 1974 tentang Perkawinan;

4. Undang-undang Nomor 7 Tahun 1984 tentang Pengesahan Konvensi mengenai Penghapusan Segala Bentuk Diskriminasi terhadap Wanita (Convension on the Elimination of All Forms of Discrimination Against Women);

5. Undang-undang Nomor 39 Tahun 1999 tentang Hak Asasi Manusia (HAM).

Selain peraturan perundang-undangan yang diterbitkan pemerintah sebelum UU PKDRT, pemerintah juga menerbitkan beberapa peraturan perundang-udangan tentang keberpihakan dan perlindungan terhadap perempuan,(Syukur, 2011, 38) yaitu:

1. Undang-undang Nomor 21 Tahun 2007 tentang Pemberantasan Tindak Pidana Perdagangan Orang;

2. Undang-undang Nomor 14 Tahun 2009 tentang pengesahan protocol to prevent, suppress and punish trafficking in persons, especially women and children, supplementing the 
united nations convention against transnational organized crime (protokol untuk mencegah, menindak, dan menghukum perdagangan orang, terutama perempuan dan anak-anak, melengkapi konvensi perserikatan bangsa-bangsa menentang tindak pidana transnasional yang terorganisasi);

3. Undang-undang Nomor 36 Tahun 2009 tentang Kesehatan yang mengakui adanya hak reproduksi perempuan.

Sekalipun upaya untuk penghapusan marital rape di Indonesia telah dilakukan bahkan negara telah menertbit UU pidana khusus tentang PKDRT, namun tindakan marital rape masih terjadi di masyarakat. Pelaku kejahatan marital rape berasal dari berbagai latar belakang, tanpa membedakan agama, suku, budaya, tingkat pendidikan, status sosial, kondisi ekonomi, jabatan, dan yang lainnya. Tindak kejahatan marital rape yang terjadi di masyarakat dikarenakan adanya faktor-faktor penyebab (Syukur, 2011, 25-36) dan sekaligus pendukung akan terjadinya tindak kejahatan tersebut, antara lain:

1. Budaya Patriarkhi

Patriarkhi merupakan sebuah sistem sosial yang menempatkan laki-laki memiliki kedudukan yang lebih tinggi dibandingkan perempuan, sehingga mampu menguasai dan mengontrol perempuan yang berada di bawahnya. Budaya patriarkhi merebak di semua lapisan masyarakat di dunia tanpa memandang perbedaan, agama, ras, budaya atau adatistiadat, maupun kondisi geografis dan geologis, termasuk di Indonesia.

Momentum reformasi yang diharapkan menjadi titik tolak perubahan dalam masyarakat Indonesia (termasuk budaya patriarkhi) pun belum mampu menggeser dominasi laki-laki di atas perempuan di berbagai aspek kebidupan berbangsa dan bernegara, seperti dalam politik, hukum, ekonomi, bahkan kehidupan keluarga. Beberapa suku dan adat di Indonesia juga masih mempertahankan dominasi laki-laki atas perempuan sebagai budaya yang harus dilaksanakan oleh anggota masyarakat. Sehingga kecenderungan munculnya KDRT atau marital rape merupakan akibat dari melekatnya budaya patriarkhi dalam masyarakat.

Suami merasa dominan kemudian melakukan kekerasan terhadap istri karena dibenarkan oleh budaya sebagai kepala keluarga yang berhak mengatur kehidupan keluarga dan anggotanya. Sedangkan istri sebagai korban kekerasan beranggapan bahwa tindakan kekerasan yang dilakukan suami adalah suatu kewajaran dalam budaya patriarkhi, paradigma ini kemudian membiarkan KDRT terus langgeng dalam masyarakat Indonesia. Maka indoktrinasi terhadap diskriminasi gender, pemberian pendidikan untuk semua jenis kelamin, akses ekonomi dan politik yang merata, dan keterlibatan perempuan dalam kegiatan yang menyangkut hajat kehidupan orang banyak di masyarakat mutlak dilaksanakan agar budaya patriarkhi bisa bergeser kepada budaya egaliter yang memberikan peran pada semua pihak tanpa adanya dikotomi antara superior dan inferior. 
2. Kesalahpahaman terhadap ajaran agama

Islam mengkategorikan relasi suami istri sebagai mitsaqan ghalidzan (ikatan yang kuat) yaitu sebuah perjanjian kuat yang disaksikan langsung oleh Allah SWT, yang berimplikasi kepada penjagaan dalam waktu yang lama oleh kedua pihak (suami-istri). Tujuan pernikahan dalam Islam adalah untuk menciptakan keluarga sakinah, mawaddah, dan rahmah.

Sebagaimana disebut dalam Q.S. ar-Rum (30): 21

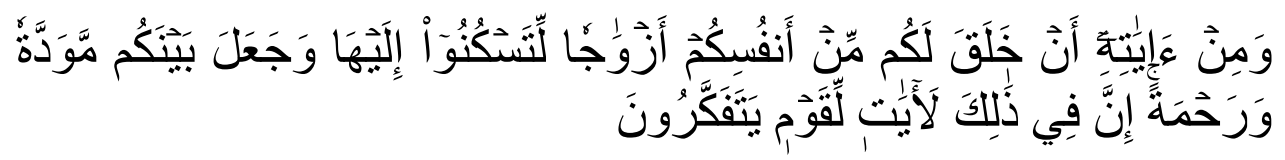

"Dan di antara tanda-tanda (kebesaran)-Nya ialah menciptakan pasanganpasangan untukmu dari jenismu sendiri, agar kamu cenderung dan merasa tentram kepadanya, dan Dia menjadikan di antaramu rasa kasih sayang. Sungguh, pada yang demikian itu terdapat tanda-tanda (kebesaran Allah) untuk kaum yang mau berpikir."

Keluarga idaman sebagaimana yang dicita-citakan agama Islam harus diwujudkan oleh suami istri. Keduanya saling bekerjasama untuk menciptakan kondisi sakinah, mawaddah, dan rahmah dalam keluarga.

Posisi suami dan istri adalah sejajar (equal) karena keduanya adalah mitra dalam keluarga, dan tidak akan terwujud cita-cita menjadi keluarga idaman, jika dalam kerjasama tidak terbangun dengan baik. Karena suami istri merupakan mitra yang sejajar, maka tidak terjadi subordinasi antara keduanya. Suami bukan pada posisi superior sedang istri inferior, yang kemudian suami mendominasi atas istri, tapi keduanya dalam posisi yang sama, yang melaksanakan peran dan fungsi masing-masing untuk mewujudkan kehidupan keluarga yang harmonis.

Penafsiran terhadap ayat al-Qur'an dan hadis dengan cara parsial dan bukan holistic mengarahkan kepada pemahaman yang tidak benar akan konsep ajaran Islam tentang kehidupan rumah tangga. Suami diposisikan sebagai kepala rumah tangga yang dianggap mempunyai kuasa penuh atas anggota keluarga. Sementara istri hanya bertugas untuk mengerjakan tugas domestik, mengurusi anak, dan melayani suami. Posisi dominan suami atas istri karena suami yang mencari nafkah keluarga, sementara istri hanya pasif menerima nafkah, maka suami berkuasa untuk mengatur rumah tangga. Kata qawwam diartikan sebagai penguasa, yang menguasai istri dan anggota keluarga lain untuk menuruti apa yang diinginkan oleh penguasa.

Firman Allah dalam Q.S. An-Nisa' (4): 34

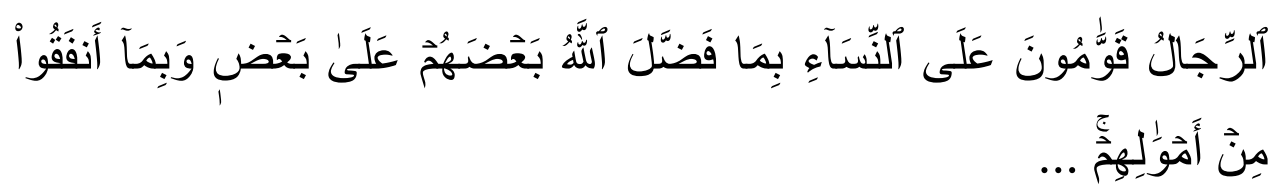

al-aḥ̂ām vol. 3, Nomor 2, 2018 
"Kaum laki-laki itu adalah pemimpin bagi kaum wanita, oleh karena Allah telah melebihkan sebagian mereka (laki-laki) atas sebagian yang lain (wanita), dan karena mereka (laki-laki) telah menafkahkan sebagian dari harta mereka..."

Berbeda jika kata qawwam diartikan sebagai pelindung, yang bertugas melindungi istri dan anggota keluarga dari bahaya yang muncul dari dalam keluarga atau datang dari luar keluarga.

Kesalahan yang lain dalam memahami konsep Islam tentang kehidupan rumah tangga, adalah dibolehkannya suami memukul istri apabila istri nusyuz. Pemahaman yang salah ini kemudian menyebabkan KDRT juga marital rape diperbolekan dalam Islam, dalam kasus istri menolak atau tidak menurut kepada suami. Sekalipun kalau dipahami secara tekstual bahwa memukul adalah usaha terkahir yang jika usaha sebelumnya sudah dilakukan namun tidak berhasil, yaitu menasehati istri dan memisahkan istri dari tempat tidur. Disebutkan dalam firman Allah dalam Q.S. An-Nisa' (4): 34

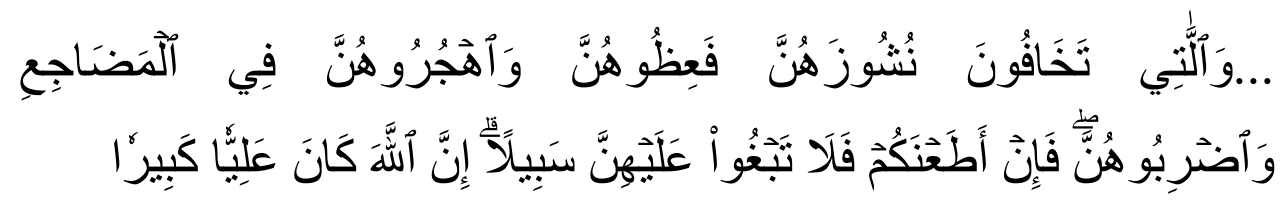

“... wanita-wanita yang kamu khawatirkan nusyuz-nya, maka nasehatilah mereka, pisahkan tempat tidurnya dan pukullah mereka, maka janganlah kamu mencari jalan untuk menyusahkan mereka. Sesungguhnya Allah Maha Tinggi lagi Maha Besar."

Pemahaman yang keliru terhadap konsep Islam tentang kehidupan rumah tangga juga posisi istri yang tidak bisa independen ketika melakukan perbuatan hukum. Istri hanya bisa melakukan suatu perbuatan hukum jika atas izin suami atau suami melakukan suatu perbuatan hukum atas istri. Sekalipun dalam ayat al-Qur'an disebutkan bahwa perbandingan persaksian antara laki-laki dan perempuan adalah 2:1, disebut dalam ayat dain (hutang) Q.S. al-Baqarah (2): 282

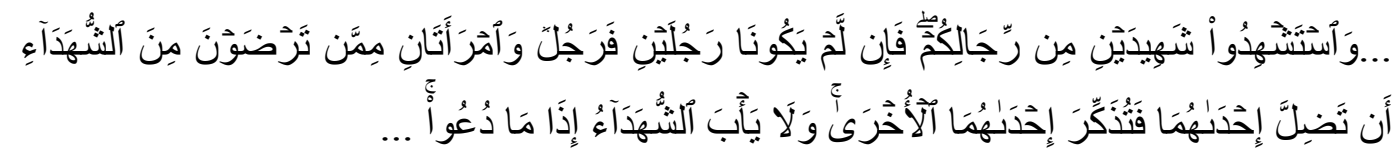

“... dan persaksikanlah dengan dua orang saksi laki-laki di antara kamu. Jika tidak ada (saksi) dua orang laki-laki, maka (boleh) seorang laki-laki dan dua orang perempuan di antara orang-orang yang kamu sukai dari para saksi (yang ada), agar jika yang seorang lupa maka ada seorang yang mengingatkannya. Dan janganlah saksi-saksi itu menolah jika dipanggil, ..."

Namun tidak kemudian menafikan posisi istri (perempuan) untuk melakukan suatu perbuatan hukum (seperti melakukan perjanjian). Karena semua orang tanpa memnbedakan 
antara laki-laki dan perempuan mempunyai hak yang sama dalam hukum, equality before the law.

3. Ketidakseimbangan kekuasaan dalam rumah tangga

Perempuan di Indonesia tidak seluruhnya mempunyai daya saing yang sama jika dibandingkan dengan laki-laki. Sekalipun reformasi birokrasi dilakukan di hampir semua aspek kehidupan bernegara, namun masih belum mensejajarkan posisi perempuan dan laki-laki. Sebagai contoh berbandingan jumlah kepala daerah dari tingkat 1 sampai yang terakhir (kepala desa atau lurah) belum bisa sepadan. Selain dalam politik, kelemahan posisi perempuan juga terjadi dalam bidang ekonomi dan sosial.

Perempuan banyak yang menggantungkan kehidupannya kepada suaminya, karena tidak bekerja dan hanya menjadi ibu rumah tangga. Namun jika perempuan memilih berkerja dan mewakilkan urusan rumah tangga kepada suami atau anggota keluarga yang lain, maka ada mendapat stigma dari masyarakat karena telah mengesampingkan urusan rumah tangga. Perempuan yang bekerja pun, masih mendapatkan ketimpangan dari lingkungan kerja dan bahkan mendapatkan kekerasan (verbal atau seksual) dari rekan kerja laki-laki di tempat kerja. Berbagai bentuk perlakuan diskriminasi terhadap perempuan (gaji, karir, kepangkatan, dan status) dan perlakuan buruk seperti pelecehan, perkosaan, dan kekerasan seksual dialami oleh perempuan dalam lingkungan kerja.(Munir, 2005, 8)such submission being portrayed as divine order. Some of the men interviewed in this study defended their dominant position by exaggerating the interpretation of religious texts that grant special privileges to men. Because of its serious repercussions on women, and because it runs counter to the basic principles of Islam on justice and equality and the overall objective of sharia, i.e. maslahat (benefit, well being

Kelemahan-kelemahan tersebut mempengaruhi posisi tawar perempuan atas posisi laki-laki dalam kehidupan. Posisi tawar yang rendah dijadikan sarana untuk tetap mendudukkan perempuan di bawah penguasan laki-laki (subordinated). Hak-hak dasar dalam kehidupan rumah tangga, seperti nafkah, biaya kebutuhan harian, uang saku anak, dan yang lainnya tidak ada ukuran yang standar, melainkan hanya turut kepada pemberian suami. Sehingga sangat mempengaruhi peri kehidupan keluarga, tumbuh kembang anak, dan tentunya kehidupan perempuan sebagai istri dan ibu dalam rumah tangga.

\section{Relasi suami istri dalam figh munakahat}

Inti dari kehidupan suami istri adalah kesetaraan (musawah) antara laki-laki dan perempuan dalam menjalankan hak dan kewajiban. Sebagaimana dikatakan dalam Q.S. alBaqarah (2): 228

al-ạ̣kām Vol. 3, Nomor 2, 2018 


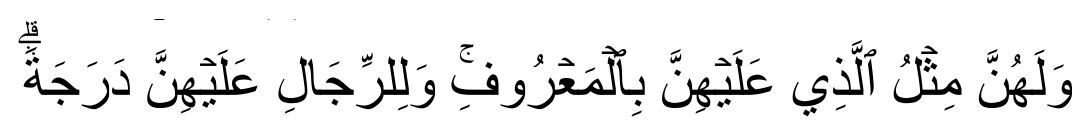

“...dan mereka (para perempuan) mempunyai hak seimbang dengan kewajibannya menurut cara yang patut (ma'ruf), dan bagi para suami mempunyai kelebihan di atas mereka ..."

Ayat di atas menjelaskan bahwa perempuan mendapatkan hak dan kewajibaen seperti halnya laki-laki. Jika perempuan diperintahkan mengerjakan sesuatu, demikian juga laki-laki diperintahkan untuk mengerjakan sesuatu.

Konsep Islam dalam kehidupan suami-istri dan keluarga merupakan konsep yang bersifat alami yang diberikan Allah kepada pasangan suami istri. Suami-istri memainkan peran masing-masing sesuai dengan kemampuan yang ada pada setiap diri pasangan. Suami yang diberikan kelebihan dalam fisik, maka suami berperan sebagai tulang punggung keluarga untuk bekerja mencari nafkah di luar rumah, sedang istri yang diberikan naluri keibuan berperan untuk mengatur rumah, mendidik anak, dan membangun suasana indah dan bahagia dalam rumah.

Tugas dan tanggung jawab yang dibebankan kepada suami adalah yang sesuai dengan kemampuan suami, begitu halnya istri bahwa tugas dan tanggungjawab yang dibebankan, sesuai dengan kemampuan istri. Rumah tangga kemudian akan menjadi teratur dan baik, ketika masing-masing antara suami dan istri melaksanakan peran yang sudah ditentukan. Suami melaksanakan kewajiban di luar rumah sedang istri melaksanakan kewajiban dalam rumah, dengan tanpa merasa bahwa salah-satu dari pasangan suami-istri menjadi superior di atas yang lain, atau inferior di bawah yang lain. Kewajiban dalam hidup berumah tangga dibebankan kepada keduanya, bukan salah satu saja antara suami atau istri.(Sabiq, 2004, 603)

Kehidupan suami-istri mensyaratkan untuk terpenuhinya hak dan kewajiban untuk masing-masing pasangan. Ada hak untuk kedua pasangan suami dan istri, hak istri yang harus dipenuhi oleh suami, dan sebaliknya terdapat hak suami yang harus dipenuhi oleh istri.(Sabiq, 2004, 577)

1. Hak untuk kedua pasangan suami istri berupa:

a. Dihalalkan untuk saling menggauli (jima') dan menikmati (istimta') antara suami istri;

b. Menjadi mahram karena hubungan semenda (mushoharah);

c. Mendapatkan hak waris dari pasangan;

d. Membentuk garis nasab, khususnya bagi suami yang menjadi ayah dari anak yang dilahirkan istri (shahibul firasy);

e. Hidup dalam pergaulan yang baik (mu'asyarah bil ma'ruf). 
2. Hak istri yang harus dipenuhi oleh suami terdiri

a. Hak materiil berupa mahar dan nafkah (sandang, pangan, dan papan)

b. Hak immaterial berupa diperlakukan dengan baik, dipenuhi kebutuhan bilogis (jima'), diperlakukan adil dan tidak sewenang-wenang.

3. Hak suami atas istri di antaranya adalah

a. Ditaati selama tidak dalam bermaksiat

b. Dijaga kehormatan diri dan hartanya

c. Mendapatkan pergaulan dengan baik.

Pemenuhan kebutuhan seksual antara suami dan istri merupakan salah satu hak suami-istri yang harus dipenuhi oleh keduanya. Walaupun bukan tujuan utama dari pernikahan, kebutuhan seksual sebagai sarana untuk mejaga keharmonisan hubungan suami istri, bahkan Islam pun memerintakan agar pasangan suami istri tidak mengabaikan akan hubungan seksual karena selain memenuhi hak suami istri, hubungan seksual antara suami istri bernilai sedekah. Sebagaimana disebut dalam H.R. Muslim:

$$
\text { .... ولك في جماع زوجنك أجر. }
$$

“... dan bagimu pahala dalam kamu mengumpuli istrimu” (Sabiq, 2004, 597)

dalam redaksi lain Rosulullah SAW bersabda:

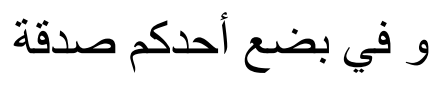

" dan dalam berhubungan seksual seorang di antara kamu adalah sedekah"(Shihab, 2007, 71)

Setiap pasangan suami-istri idealnya mampu menguasai ketrampilan dalam hubungan seksual. Ketrampilan seksual meliputi; frekuensi hubungan seksual, keaktifan pasangan, keberanian mengungkapkan kepuasan dalam hubungan seksual, gairah seksual, dan penguatan fungsi seksual. Karena hubungan seksual antara suami-istri merupakan salah satu aspek penting dalam kehidupan rumah tangga. Jika pasangan suami-istri terampil dalam hubungan seksual, maka akan berpengaruh terhadap kepuasan antar pasangan, yang kemudian menambah keharmonisan rumah tangga, sedang jika ketrampilan hubungan seksual diabaikan oleh suami-istri maka akan memunculkan masalah dalam kehidupan rumah tangga, dan menjadi pemicu dalam putusnya hubungan perkawinan antara suami dan istri.(Junaidi, 2013, 170-171)

Pemenuhan kebutuhan seksual antara suami dan istri harus dilandasi dengan nilainilai agama. Karena seks bukanlah sesuatu yang kotor melainkan suci dan harus dijaga kehormatannya. Allah sebagai al-Khaliq sangat paham dengan keadaan manusia yang diberi kecenderungan untuk senang kepada pasangannya, maka dibuatlah syariat untuk 
mengatur agar tetap terjaga kehormatan manusia dalam memenuhi kebutuhan seksual kepada pasangannya. Firman Allah dalam Q.S. al-Baqarah (2): 187.

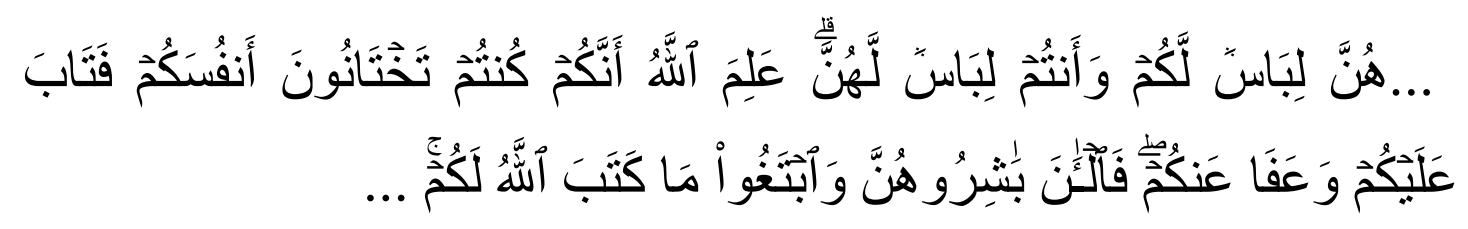

“... dan mereka (istri-istrimu) adalah pakaian bagimu, begitu pula kamu adalah pakaian bagi mereka. Allah mengetahui bahwa kamu tidak dapat menahan nafsumu, karena itu Allah mengampuni kamu dan memberi maaf kepadamu. Maka sekarang campurilah mereka (istri-istrimu) dan carilah apa yang ditetapkan Allah untukmu ..."

Juga dalam Q.S. al-Baqarah (2) ayat 223, Allah berfirman:

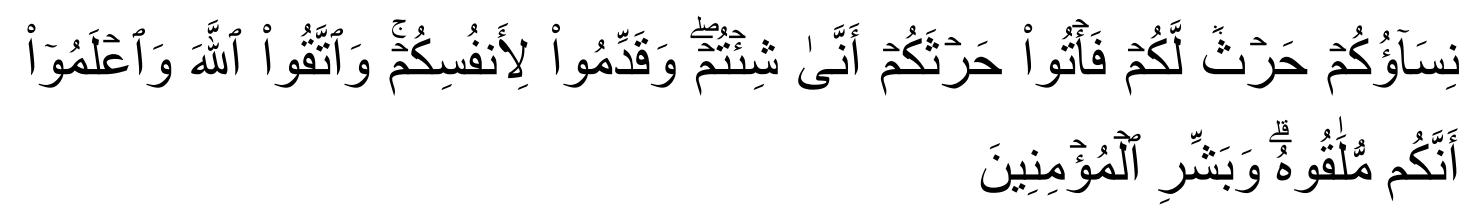

\begin{abstract}
"Istri-istrimu adalah ladang bagimu, maka datangilah ladang kamu bagaimana saja kamu inginkan, dan utamakanlah yang baik untuk dirimu. Bertaqwalah kepada Allah dan ketahuilah bahwa kamu akan menemui-Nya. Dan sampaikanlah kabar gembiara bagi orang-orang yang beriman"
\end{abstract}

Nilai-nilai agama yang mendasari pemenuhan hubungan seksual akan memberikan dampak positif dan kesan yang indah kepada pasangan suami-istri, yang bukan hanya terhenti pada kepuasan akan terpenuhinya hasrat seksual tapi juga kenyamanan dan ketentraman dalam hati pasangan suami-istri karena melakukan sesuatu yang berlandaskan nilai agama. Agar pemenuhan kebutuhan seksual sesuai dengan yang diperintahkan Allah SWT dan Rosulullah SAW, sebaiknya sebelum melakukan hubungan seksual, suami dan istri untuk membaca doa dan meminta perlindungan dari Allah SWT, termasuk ketika mendapatkan kepuasan seksual, suami-istri pun tetap untuk mengingat kepada Allah yang Maha Pemberi nikmat, yang oleh kaum sufi mengajarkan nikah batin, yaitu ketika terjadi orgasme suami dan istri saling menjabat tangan dan mempertemukan ibu jari masing-masing sambil membaca dua kalimat syahadat. (Shihab, 2007, 74)

Selain melaksanakan sejumlah perintah dalam melakukan hubungan seksual, suamiistri juga harus memperhatikan sejumlah larangan yang harus dijauhi dalam melakukan hubungan seksual,(Susilo, 2013, 325) yaitu: 
1. Tidak melakukan hubungan seksual selama menjalankan puasa Ramadhan;

2. Tidak melakukan hubungan seksual ketika istri sedang masa haid (menstruasi);

3. Dilarang melakukan hubungan suami istri ketika istri nifas;

4. Dilarang melakukan hubungan badan melalui dubur (anal sex).

Hubungan seksual antara suami dan istri yang berdasarkan kepada aturan-aturan dan nilai-nilai agama, bukan hanya untuk memenuhi nafsu syahwat semata melainkan juga menjalankan perintah agama sebagai sarana mendapatkan ridho Allah SWT.

Inisiasi melakukan hubungan seksual bukan hanya datang dari pihak suami saja, tapi istri pun juga mempunyai hak yang sama dalam hubungan seksual. Karena suami-istri adalah pasangan yang saling melengkapi dan memenuhi keinginan dari masing-masing. Hubungan seksual harus dinikmati oleh keduanya, bukan hanya salah satu pasangan suamiistri saja.(Susilo, 2013, 327) Maka ketika suami ingin melakukan hubungan seksual sedang istri sedang dalam keadaan yang tidak ingin melakukan, istri harus rela berkorban untuk memenuhi kebutuhan suaminya, dan ketika istri menginginkan hubungan seksual dalam keadaan suami tidak berkeinginan, maka suami harus rela untuk memenuhi kebutuhan istrinya tanpa merendahkan atau melecehkan keinginan istri.

Pemahaman yang sering keliru di tengah masyarakat bahwa keinginan untuk berhubungan suami isteri datang dari suami, maka ketika suami menginginkan untuk melakukan jima' isteri harus menuruti kemauan suami. Sementara isteri tidak boleh dengan tegas menyatakan keinginan untuk melakukan hubungan seksual kepada suami, karena yang demikian dianggab sesuatu yang tabu.(Asy-Syadzali, 2012, 287)Karena antara suami istri terdapat hubungan patnership yang sejajar untuk saling memenuhi kebutuhan satu dengan yang lain (mutualisme).

\section{Konsepsi Marital Rape dalam Fiqih Munakahat}

Konsep marital rape dalam literatur fiqih Islam sulit untuk didapatkan, karena dalam kehidupan keluarga antara suami dan istri tidak dikenal istilah "perkosaan" yang dilakukan suami kepada istri. Perkosaan (al-wath'u bil ikrah) yang diatur dalam fiqih Islam, adalah perempuan yang dipaksa untuk melakukdian hubungan seksual dengan seorang laki-laki, yang tidak ada hak untuk laki-laki tersebut melakukan hubungan seksual kepada perempuan yang diperkosanya. Sayyid sabiq menggunakan istilah zina, karena hubungan seksual dilakukan dengan orang asing, bukan istri atau budak.(Sabiq, 2004, 733)

Pembahasan mengenai perkosaan pun umumnya hanya dibatasi kepada had (hukuman), bahwa perempuan yang menjadi korban perkosaan tidak dikenai hukuman atas hubungan badan yang dilakukannya dengan laki-laki yang memaksanya, karena dalam keadaan dipaksa maka bebas dari hukuman. Dasar hukumnya dalam Q.S. al-Baqarah (2): 173

al-ạ̣kām Vol. 3, Nomor 2, 2018 


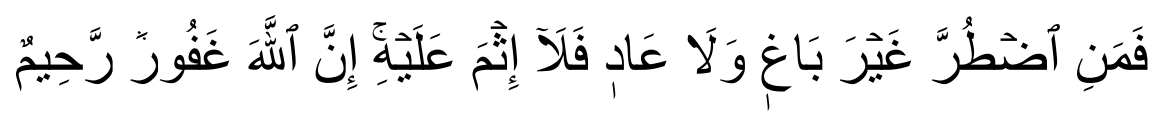

“... tetapi barang siapa terpaksa, bukan karena menginginkannya dan tidak pula melampaui batas, maka tidak ada dosa baginya. Sungguh, Allah Maha Pengampun, Maha Penyayang."

Pelaku perkosaan dalam fiqih Islam dibagi ke dalam dua kategori; pertama, perkosaan yang dilakukan tanpa ancaman senjata atau membunuh, pelaku akan dikenai denda membayar mahar jika korban adalah perempuan merdeka (gadis atau yang sudah menikah), sedangkan jika budak dikenai denda sekurang-kurangnya sama seperti harga budak wanita tersebut. Menjadi paradoks ketika perzinahan hukumannya adalah dicambuk 100 kali ditambah dengan diasingkan untuk pelaku zina ghaira muhson, dan dirajam untuk pelaku zina muhson baik laki-laki maupun perempuan. Maka diperlukan ijtihad untuk menentukan hukuman tegas bagi pelaku perkosaan, sehingga memberikan efek jera bagi pelakunya dan peringatan kepada masyarakat untuk tidak melakukan kejahatan perkosaan. Kedua, jika melakukan dengan senjata atau ancaman membunuh, maka diqiyaskan dengan had perampok yaitu dibunuh, disalib, dipotong tangan dan kaki secara silang, atau diasingkan (bisa diganti dengan penjara).(Baits, 2011)

Hubungan seksual dalam fiqh munakahat merupakan hak suami dan istri untuk dipenuhi, sebagai konsekuensi dari pernikahan dan merupakan sarana untuk mendapatkan tujuan pernikahan yaitu mendapatkan keturunan. Hubungan seksual antara suami dan istri dapat berjalan dengan baik, jika kedua pasangan menyadari bahwa hubungan seksual harus dilandasi dengan kerelaan antara dua pihak. Maka tidak dibenarkan suami memaksakan hubungan seksual kepada istri yang tidak siap untuk melayani, jika demikian yang terjadi suami harus bersabar untuk menunggu waktu istri siap melayani, begitu pula istri juga ketika menginginkan hubungan seksual tidak dibolehkan memaksaka suaminya untuk melakukan, melainkan bersabar sampai kemudian suaminya siap untuk melakukan bersama-sama.

Konsep mu'asyarah bil ma'ruf adalah konsep fiqih munakahat dalam hubungan suami istri. Hubungan suami-istri harus dilandasi dengan asas kebaikan dan kepatutan termasuk dalam hubungan seksual. Sebagaimana yang diperintahkan Allah dalam Q.S. anNisa' (4): 19

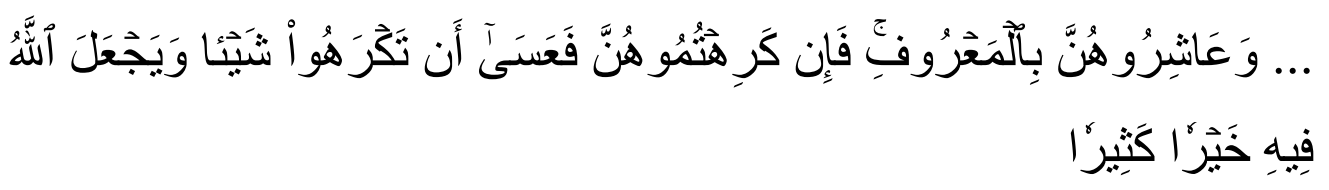

“... dan bergaullah dengan mereka secara ma'ruf (patut). Selanjutnya bila kamu tidak menyukai mereka, (maka bersabarlah) karena boleh jadi kamu tidak menyukai sesuatu, padahal Allah menjadikan padanya kebaikan yang banyak"(Shihab, 2002, 380) 
Kata 'asyiru yang terkandung dalam ayat di atas dalam bentuk kata amr (perintah), yang kemudian jika menggunakan kaidah fiqih bahwa setiap perintah menunjukkan kewajiban (al-aslu fil amri lil wujub illa ma dalla dalilun 'ala khilafihi). Perintah menggauli istri dengan baik (patut), yaitu dengan tidak mengganggu, tidak memaksa, berbuat ihsan, dan berbaik-baik kepada istri, merupakan kewajiban setiap suami dalam menjalankan kehidupan berumah tangga.(Shihab, 2002, 382)Mafhum mukhalafah-nya adalah jika suami memaksakan hasrat seksualnya kepada istri dengan cara yang tidak benar, maka telah menyalahi ketentuan dalam fiqih munakahat yang hukumnya adalah haram dan mendapatkan dosa dari Allah SWT.

Salah satu bentuk pemaksaan suami atas istri adalah melakukan hubungan seksual dengan cara yang keluar batas kewajaran (contoh analsex). Perilaku seksual yang menyimpang ini bisa saja dilakukan suami atas istri karena mengganggap istri adalah "properti" milik suami, yang diperlakukan bebas sesuai dengan keinginan suami. Sekalipun dalam al-Qur'an disebutkan bahwa istri adalah ladang bagi suami (nisa'ukum hartsu lakum) bukan diartikan suami bebas menggauli istri dengan cara apapun termasuk anal sex. Kata "ladang" adalah tempat bercocok tanam, yaitu tempat meletakkannya suami dengan benih yang nantinya tumbuh menjadi anak sebagai keturunan dari bapak dan ibu. Maka "datangilah sesukamu" adalah dengan cara bagaimanapun suami menggauli istrinya, namun masih dalam batas tempat reproduksi wanita yaitu vagina (qubul).(Sabiq, 2004, 598)

Memaksakan hubungan seksual kepada istri adalah perbuatan yang melanggar syariat, karena pada dasarnya hubungan seksual antara suami istri dilakukan dengan saling ridho (taradhin) dan dengan cara yang patut (ma'ruf). Apalagi jika suami memaksa istri melakukan hubungan seksual dengan cara yang tidak dibenarkan (anal sex). Selain diharamkan oleh syariat, menggauli istri dari dubur adalah bertentangan dengan tabiat (fitrah) manusia dan juga membahayakan untuk kesehatan karena dubur adalah tempat yang kotor.(Alhafidz, 2010, 241) Rosulullah mengancam suami yang mendatangi istrinya dari dubur dengan sebutan "luthiyah asy-sughra" (perbuatan liwath kecil), yang kemudian oleh Ibnu Taimiyyah dikatakan bahwa suami yang melakukan liwath kepada istrinya harus diberi ta'zir,(Sabiq, 2004, 599)dengan diberi hukuman dengan tujuan mendidik dengan cara dipukul, disumpahi, atau dipenjara atas suatu perbuatan maksiat yang tidak ditentukan hukumannya (had) dan kaffarat-nya oleh Allah SWT.(Aljazairi, 2000, 425)dan jika menolak maka suami istri tersebut harus dipisahkan.

Sekalipun dalam fiqih sudah ditegaskan hukuman bagi suami yang memaksakan hubungan seksual kepada istri (marital rape), namun hanya dibatasi dalam masalah liwath dan tidak ditegaskan untuk pemaksaan atau kekerasan seksual dalam bentuk yang lainnya. Idealnya perlu diformulasikan ketentuan khusus dalam fiqih munakahat yang mengatur larangan yang tegas terhadap semua bentuk kekerasan seksual yang dilakukan suami atas

al-ạ̣kām Vol. 3, Nomor 2, 2018 
istri, sehingga memberikan peringatan kepada masyarakat sekaligus ancaman atau efek jera kepada para pelaku marital rape. Sebagaimana yang telah ditetapkan oleh UU Nomor 23 Tahun 2004 tentang PKDRT pasal 47 yang berbunyi:

"Setiap orang yang melakukan perbuatan kekerasan seksual sebagaimana dimaksud dalam Pasal 8 huruf a dipidana dengan pidana penjara paling lama 12 (dua belas) tahun atau denda paling banyak Rp 36.000.000,00 (tiga puluh enam juta rupiah)."

\section{Kesimpulan}

Allah menciptakan manusia laki-laki dan perempuan adalah untuk berpasangan menjadi suami dan istri. Setiap pasangan suami dan istri diciptakan rasa ketenangan, cinta, dan kasih sayang (sakinah, mawaddah wa rahmah). Jika seseorang telah diberikan rasa mawaddah maka rela mengorbankan segalanya untuk seseorang yang dicintainya. Kesediaan suami untuk memberikan segala kebaikan kepada istrinya dan mengorbankan diri untuk istri yang dicintainya adalah tanda bahwa sudah tumbuh rasa mawaddah dalam dirinya, begitu pula istri yang rela meninggalkan orang tua dan keluarga besarnya, kemudian hidup bersama dengan laki-laki yang menjadi suaminya, serta bersedia membuka rahasia yang paling dalam merupakan wujud dari cinta dan kasih sayang istri kepada suaminya. (Shihab, 2002, 21)

Menciptakan suasana harmonis dalam kehidupan berumah tangga adalah tugas bersama antara suami dan istri, karena suami istri adalah mitra yang mempunyai posisi yang sama dalam keluarga. Sekalipun suami dalam al-Qur'an disebut dengan kata qawwam yang berarti pemimpin, bukan berarti suami mejadi superior atas istri, melainkan berperan sebagai pelindung istri dan anggota keluarga yang lain dari bahaya yang muncul dalam rumah tangga, ataupunnn yang datang dari luar rumah tangga. Selain berperan sebagai pelindung, suami juga berkewajiban untuk memenuhi salah satu hak istri yang paling mendasar yaitu menggauli istri dengan baik (mu'asyarah bil ma'ruf).

Memperlakukan istri dengan hormat, menggauli dengan baik, memprioritas istri, dan menjalani kehidupan bersama istri dengan kesabaran merupakan kewajiban yang harus dijalankan oleh setiap suami. Menggauli istri dengan baik adalah cerminan pribadi utama dalam diri suami, namun sebaliknya jika memperlakukan istri dengan cara yang tidak baik menunjukkan ciri seorang lalim. Sebagaimana yang digambarkan Rosulullah dalam hadis:

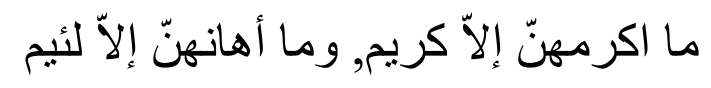

"Tiada seorang yang menghormati wanita-wanitanya melainkan orang yang mulia, dan tiada yang menghinakan wanita-wanitanya kecuali orang yang buruk (la'im)"(Sabiq, 2004, 594) 
Suami memperlakukan istri dengan hormat adalah dengan cara memposisikan istri sejajar dengannya, tidak memaksa dan menyakiti istri, sekalipun dengan ucapan ofensif (kalimatun nabiyah). Sehingga akan tercipta suasana harmonis antara saumi dan istri di tengah kehidupan rumah tangga.

\section{Daftar Pustaka}

Alhafidz, A. W. (2010). Fikih Kesehatan. Jakarta: Amzah.

Aljazairi, A. B. J. (2000). Minhajul Muslim. Kairo: Dar as-Salam.

Asy-Syadzali, K. (2012). Seteguk Cinta: Kamasutra Arab. (M. Misbah, Ed.). Jakarta: Amzah.

Baits, A. N. (2011). Hukum Kasus Pemerkosaan. Retrieved from https://konsultasisyariah. com/3966-hukum-kasus-pemerkosaan.html

Bosch, K. (2007). When words are used as waepons: Verbal Abuse. NebGuide, (November 2007), 1-3. Retrieved from http://www.ianrpubs.unl.edu/epublic/live/g1814/build/ g1814.pdf

Junaidi, A. (2013). Pernikahan Hybrid: Studi tentang Komitmen Pernikahan Wong Nasional di Desa Patokpicis Kecamatan Wajak Kabupaten Malang. Yogyakarta: Pustaka Pelajar.

Martha, A. E. (2003). Perempuan, Kekerasan, dan Hukum. Yogyakarta: UII Press.

Martha, A. E. (2011). Proses Pembentukan Hukum Kekerasan terhadap Perempuan di Indonesia dan Malaysia. Yogyakarta: Aswaja Pressindo.

Munir, L. Z. ( C. for P. and D. S. (2005). Domestic Violence in Indonesia. Muslim World Journal of Human Rights, 2(1), 1-37.

Sabiq, S. (2004). Fiqh sunnah. Kairo: Dar al-Hadis.

Shihab, M. Q. (2002). Tafsir al-Misbah: Pesan, Kesan dan Keserasian al-Qur'an. Jakarta: Lentera Hati.

Shihab, M. Q. (2007). Pengantin al-Qur'an: Kalung Permata buat Anak-anakku. Jakarta: Lentera Hati.

Soeroso, M. H. (2012). Kekerasan dalam Rumah Tangga dalam Perspektif YuridisViktimologis. Jakarta: Sinar Grafika.

Susilo, M. E. (2013). Islamic Perspective on Marital Rape. Jurnal Media Hukum, 20(2).

Syukur, F. A. (2011). Mediasi Perkara KDRT (Kekerasan dalam Rumah Tangga): Teori dan Praktek di Pengadilan Indonesia. Bandung: Mandar Maju.

al-aḥkäm vol. 3, Nomor 2, 2018 